\title{
Bioprospecting of cow's ruminal microbiota from a slaughterhouse in Ambarawa, Central Java, Indonesia
}

\author{
RETNO MURWANI ${ }^{1,2}$, MADA TRIANDALA SIBERO ${ }^{2,3, \bullet}$, POLA RISDA ASWITA SILITONGA ${ }^{2,3}$, \\ AMBARIYANTO AMBARIYANTO ${ }^{2,3}$ \\ ${ }^{1}$ Faculty of Animal and Agricultural Science, Universitas Diponegoro. J1. Prof. Soedarto SH, Semarang 50275, Central Java, Indonesia \\ ${ }^{2}$ Natural Product Laboratory, Integrated Laboratory for Research and Services, Universitas Diponegoro. J1. Prof. Soedarto SH, Semarang 50275, Central \\ Java, Indonesia \\ ${ }^{3}$ Faculty of Fisheries and Marine Science, Universitas Diponegoro. Jl. Prof. Soedarto SH, Semarang 50275, Central Java, Indonesia. \\ Tel./fax.: +62-24-7474698, `email: madatriandalasibero@lecturer.undip.ac.id
}

Manuscript received: 6 September 2021. Revision accepted: 25 October 2021.

\begin{abstract}
Murwani R, Sibero MT, Silitonga PRA, Ambariyanto A. 2021. Bioprospecting of cow's ruminal microbiota from a slaughterhouse in Ambarawa, Central Java, Indonesia. Biodiversitas 22: 5030-5038. Ruminal microorganisms play essential roles in maintaining ruminant health. However, most studies focused only on ruminal lactic acid bacteria (LAB), although other ruminal microorganisms might have biological properties for biotechnological purposes. Therefore, the current study aimed to isolate ruminal bacteria (LAB and non-LAB) and fungi from ruminal material and conducted a bioprospecting study to understand their ability to produce antibacterial compounds and polysaccharide-degrading enzymes. The ruminal bacteria were isolated on MRS and ISP4 agar, while PDA was used to isolate the different fungi. The antibacterial property was tested against multidrug-resistant Escherichia coli and Salmonella enterica ser. Typhi. The ability to produce agarase, alginate-lyase, and carrageenase was screened. Prospective isolates were identified using DNA barcoding approach. Twelve bacteria were isolated using MRS agar, six from ISP4 agar, and four fungi from PDA. Among twelve bacteria from MRS agar, eleven were considered LAB, which consisted of Lactobacillus plantarum and Pediococcus acidilactici. Several classes of bacteria such as actinobacteria, firmicutes, $\gamma$-proteobacteria, and $\beta$-proteobacteria were isolated during this study. In addition, three fungal classes, namely Saccharomycetes, Eurotiomycetes, and Mucoromycetes were also isolated. All bacteria from MRS agar were suggested to have potential compounds with antimicrobial activity, while all ruminal fungi exhibited potential sources of polysaccharide-degrading enzymes.
\end{abstract}

Keywords: Actinobacteria, bioprospecting, fungi, Indonesia, LAB

Abbreviations: ISP4: International Streptomyces Project 4; LAB: lactic acid bacteria; MRS: De Man, Rogosa and Sharpe; PDA: Potato Dextrose Agar

\section{INTRODUCTION}

Rumen is a unique and complex ecosystem containing various nutrients and an aerobic microorganisms (Matthews et al. 2019). The microorganisms live symbiotically to digest the leaves and greens containing high fiber, low protein, and fat. The ruminal microorganisms produce certain essential enzymes to digest the nutrients in the rumen and the host could use the product for other metabolism (Wang and McAllister 2002) The ruminal fermentation converts the feed into several substances such as volatile fatty acids (VFAs) and lactic acid (Balch and Rwoland 1957; Castillo-González et al 2014; Wang et al. 2012). The lactic acid is the result of soluble carbohydrates fermentation by the ruminal microorganisms. Furthermore, besides bacteria, fungi are also reported as one of the eukaryotic organisms that live inside a cow's rumen (Tapio et al. 2017).

Most of the studies on ruminal microorganisms focused on lactic acid bacteria (LAB) due to their ability to be developed as probiotic agents in food and feed industries. Probiotic is defined as a group of microorganisms that confer health benefits if administered adequately (Nagpal et al. 2012). Several genera such as Bifidobacteria, Enterococcus, Lactobacillus, Pediococcus, and Weissella are commonly isolated as LAB from a wide range of hosts (Han et al. 2014; Górska et al. 2019). In addition, plenty of bioprospecting studies demonstrate the beneficial effect of consuming LAB. Bioprospecting is a study used to obtain valuable products from bioresources that can be developed for commercialization (Pushpangadan et al. 2018).

A previous study stated that the consumption of LAB as a probiotic was observed to positively affect body weight loss to prevent obesity (Ejtahed et al. 2019). Kocsis et al. (2020) stated that probiotic helps type 2 diabetes mellitus patients with elevated HDL, improve dyslipidemia and induce a better metabolic control. Furthermore, some probiotic LABs can inhibit cell proliferation and induce apoptosis in cancer cells (Górska et al. 2019). Among all biological properties, LAB is well known as the producer of antimicrobial compounds against several pathogens such as Escherichia coli, Enterococcus faecalis, Listeria innocua, Bacillus cereus, Staphylococcus aureus, and Staphylococcus epidermidis (Mezaini et al. 2009; Jannah et al. 2018). A recent study discovered the therapeutic 
potential of LAB in the treatment of Helicobacter pylori induced colon cancer (Techo et al. 2019).

Ruminal microorganisms besides LAB have been widely reported to produce carbohydrate-degrading enzymes (Dai et al. 2015). Jose et al. (2017) discovered some bacterial genera such as Clostridium, Bacteroides, and Prevotella which produce the highest carbohydratedegrading enzymes among other genera isolated from Indian crossbred cattle. Another study reported that Butyrivibrio spp. from ruminant livestock produces various polysaccharide-degrading and carbohydrate-utilizing enzymes (Palevich et al. 2020). Besides bacteria, ruminal fungi also play an important role in plant cell wall degradation through enzymatic bioprocess. Several species of ruminal fungi known to produce polysaccharidedegrading enzymes are Anaeromyces robustus, Neocallimastix patriciarum, Orpinomyces sp., and Piromyces equi (Comlekcioglu et al. 2010; Dai et al. 2015; Swift et al. 2019).

Polysaccharide is a large carbohydrate molecule consisting of $>10$ monosaccharide or disaccharide units joined by glycosidic linkages (Yu et al. 2018). Interestingly, recent studies revealed that the oligosaccharides have distinct biological activities than their polymer. Oligosaccharide is defined as a macromolecule formed by 2-10 monosaccharides (Mano et al. 2017), although some may be longer than 10. Recent studies reported that marine oligosaccharides could be obtained from various sources especially derivative of agar, alginate, and carrageenan show remarkable biological activities such as antitumor, anti-hypertensive, antidiabetic, antioxidant, antimicrobial and immunomodulatory properties (Liu et al. 2019; Nordgård et al. 2019; Zhu et al. 2020). It triggers a broad application of these molecules in functional food, nutraceuticals, cosmetics, and biomedicine industries (Jutur et al. 2016). Furthermore, marine oligosaccharides could be produced using microbial enzymes to produce a prebiotic (Hu et al. 2006; Gurpilhares et al. 2019; Liu et al. 2019).

The potential of ruminal microorganisms to produce polysaccharide-degrading enzymes is expected to produce oligosaccharides from various other sources. However, a study on discovering the enzyme revealed that marine polysaccharide degrading enzymes from ruminal microorganisms are rarely reported. In addition, LAB from the rumen has prospects of being developed into a functional product. Therefore, we attempt to isolate cow ruminal bacteria and fungi from a cow, screen the ability of ruminal microorganisms to produce antimicrobial compounds and marine polysaccharide-degrading enzymes, then identify the potential strains using DNA barcoding.

\section{MATERIALS AND METHODS}

\section{Rumen material}

Greens and fluids from a cow's rumen were collected from a slaughterhouse in Ambarawa, Central Java, Indonesia. This slaughterhouse is a pool for local cattlemen around Ambarawa who breed domestic cows. Hence, the rumen greens and fluid were collected from a newly slaughtered domestic cow, then transferred into a sterilized plastic and brought to Laboratory Natural Product, Universitas Diponegoro, Semarang, Indonesia for microbial isolation.

\section{Bacterial isolation}

De Man, Rogosa and Sharpe agar (MRSA from HiMedia), International Streptomyces Project 4 agar (ISP4 from Difco ${ }^{\mathrm{TM}}$ ), and Potato Dextrose Agar (PDA from HiMedia) were prepared to isolate $\mathrm{LAB}$, non-LAB, and fungi from the sample. Bacterial isolation was carried out according to Guo et al. (2020) with the serial dilution method. One gram of sample was transferred into $9 \mathrm{~mL}$ of physiological saline solution $(0.8 \% \mathrm{NaCl})$ to obtain the first dilution $\left(10^{-1}\right)$. Further, the dilution was continued to reach $10^{-6}$. Afterward, $100 \mu \mathrm{L}$ of each dilution was transferred onto agar media (MRSA, ISP4 agar, and PDA) then incubated at $37^{\circ} \mathrm{C}$ for seven days. Bacterial and fungal growth was observed every day. The bacteria grew after $1 \times$ $24 \mathrm{~h}$ while fungi grew after $2 \times 24 \mathrm{~h}$ of incubation. Each colony was transferred into a new agar plate to obtain a single colony. All pure isolates were cultured and vacuumed inside a sealer plastic (Krisbow) before incubation to understand the need for oxygen in their respiration.

\section{Screening of Lactic Acid Bacteria (LAB)}

All isolated bacteria using MRSA were screened to confirm as a LAB by inoculating all bacterial isolates onto MRS agar supplemented with $1 \% \mathrm{CaCO}_{3}$ then incubated at $37^{\circ} \mathrm{C}$ for $2 \times 24 \mathrm{~h}$ in aerobic and anaerobic conditions. The anaerobic condition was obtained by incubating the plate inside a plastic vacuum bag (KRIS), and then the air was sucked by a vacuum sealer (KRIS Hp51). The acidproducing bacteria secreted the acid to degrade the $\mathrm{CaCO}_{3}$ then formed a clear zone around the colony. Further, the prospective colonies were selected based on the ability to degrade the $\mathrm{CaCO}_{3}$, confirmed as gram-positive, and gave a negative result for the catalase test (Monika et al. 2017)

\section{Screening of antibacterial activity}

In this study, multidrug-resistant (MDR) E. coli and Salmonella enterica ser. Typhi were obtained from Dr. Kariadi General Hospital in Semarang, Central Java. The bacteria were identified as clinical MDR pathogens. The antibacterial screening was done by an agar plug method (Ayuningrum et al. 2019; Sibero et al. 2019). All isolates were cultivated on agar media for four days for the bacteria and seven days for fungi. The pathogens were cultivated on Meuller Hinton Agar (MHA) (HiMedia) for $24 \mathrm{~h}$ before the assay. Then, the pathogen was suspended into Mueller Hinton Broth (MHB) (HiMedia) to reach turbidity of 0.5 McFarland. The pathogen suspension was inoculated onto MHA evenly. After that, the ruminal isolates and their agar were cut in a circle shape, transferred, put onto the inoculated MHA, then incubated for $24 \mathrm{~h}\left(37^{\circ} \mathrm{C}\right)$. The presence of an inhibition zone around the agar plug indicated the antibacterial activity of each isolate. 


\section{Screening of polysaccharide-degrading enzymes}

This step was conducted using agar media with the addition of specific marine polysaccharides (Ayuningtyas et al. 2021; Hutapea et al. 2021; Wijaya et al. 2021). Agar, alginate, and carrageenan were the marine polysaccharide that was used in this study. Therefore, agarase, alginatelyase and carrageenase were the target enzymes in this study. The screening media used contain $2 \%$ agar, $0.1 \%$ yeast, $0.5 \%$ peptone, $0.2 \%$ specific marine polysaccharide. The plates were incubated at $37^{\circ} \mathrm{C}$ for three days. Iodine solution was poured onto the plate then set for one hour. The presence of clear zones around the colony indicated enzyme activity.

\section{Ruminal microorganisms identification}

The DNA was extracted using Quick DNA Fungal/Bacterial MiniPrep ${ }^{\mathrm{TM}}$ Kit (Zymo Research). The PCR mixture consisted of $12.5 \mu \mathrm{L}$ GoTaq ${ }^{\circledR G}$ Green Master Mix (Promega), $1 \mu \mathrm{L}$ DNA template, $1 \mu \mathrm{L}$ primer forward, $1 \mu \mathrm{L}$ primer reverse then $\mathrm{ddH}_{2} \mathrm{O}$ until total of the final mixture reached $25 \mu \mathrm{L}$. Primers 27F (5'-AGA GTT TGA TCM TGG CTC AG-') and 1492R (5'- GGT TAC CTT GTT ACG ACT T-3') were applied for bacteria (Sibero et al. 2019; Wijaya et al. 2020), while ITS1 (5'-TCC GTA GGT GAA CCT GCG G-3') and ITS4 (5'-TCC TCC GCT TAT TGA TAT GC-3') for fungi (Sibero et al. 2017). Amplification was performed with the following condition: denaturation at $95^{\circ} \mathrm{C}$ for $1 \mathrm{~min}$, annealing at $55^{\circ} \mathrm{C}$ for 1 min, extension at $72^{\circ} \mathrm{C}$ for $1 \mathrm{~min}$ for 32 cycles. Gel electrophoresis in agarose $1 \%$ was carried out to check the PCR product then sent to 1st Base Laboratories Sdn Bhd, Malaysia for sequencing. Then the sequence was used to determine the species by comparing to GenBank data using Basic Local Alignment Search Tool (BLAST) in NCBI. The phylogenetic tree was reconstructed using MEGA 7 software package.

\section{RESULTS AND DISCUSSION}

The ruminal microbiome plays an essential role in feed efficiency, production of methane emissions, volatile fatty acids, and lactic acid that promote the growth and health of the host ( $\mathrm{Li}$ and Guan 2017; Paz et al. 2018; Tapio et al. 2017; O'Hara et al. 2020). The feed variation and alteration also impact the microbial composition and diversity in the rumen (Noel et al. 2019; Wang et al. 2019). Most studies applied metagenomics and metatranscriptomic to elucidate the diversity of culturable and unculturable microbiota, along with their interaction in the rumen (Dai et al. 2015; Jose et al. 2017). In this study, the culturable microbial composition from cow rumen was investigated using three different media. The results of microbial isolation on different growth media are presented in Figure 1.

The microbial isolation results revealed isolation of twelve bacteria from MRS agar, six bacteria from ISP4 agar, and four fungi from PDA (Fig. 1). The isolation media, ISP4 agar and PDA gave fewer microbial colonies than MRSA (Fig. 2). It was suggested that the insufficient nutrient contents in ISP4 and PDA might be possible to isolate diverse taxa of microorganisms from the rumen. As nutrient content in the media is essential to the growing diverse taxon of the cultivated microorganisms, several media are designed to isolate specific microbial taxa such as MRSA for lactic acid bacteria, ISP4 agar for Streptomyces spp. and other actinobacteria, while PDA for fungi; however, other taxa may grow during the incubation (Kharel et al. 2010; Nero et al. 2006; Sibero et al. 2018). In addition, the nutrient rich media was observed to gain more microorganisms rather than the poor nutrient media (Trianto et al. 2020). MRSA plates were incubated in vacuumed conditions during the isolation treatment, while ISP4 and PDA plates were without vacuum. This treatment is also suspected to impact the number of isolated ruminal microorganisms in ISP4 and PDA, even less most of the ruminal microorganisms are anaerobic (Comlekcioglu et al. 2010; Tapio et al. 2017).

Subsequently, all isolates were grown in aerobic and anaerobic conditions to understand their need for oxygen. The characteristic of colonial morphology and respiration is shown in Table 1.

The results of respiration test are presented in Table 1, which shows 19 isolates (86.4\%) grew in aerobic and anaerobic conditions. Therefore, these isolates were suggested as a facultative anaerobe. It means that the microbes can grow in both the presence or absence of oxygen even though they grow better in aerobic conditions (Stieglmeier et al. 2009). Among all isolates, three bacteria $(13,6 \%)$ were noted as aerobic bacteria. Aerobic microorganisms need oxygen to grow, hence they did not grow in vacuum incubation. Jami et al. (2013) stated that several aerobic taxa were found in the rumen, but these taxa declined during the maturation. It was suggested that diet and feeding behavior attributed to the composition alteration of aerobic and anaerobic microorganisms in the rumen. Further, all isolates were screened to observe their ability to produce marine polysaccharide-degrading enzymes and antimicrobial agents to combat MDR pathogens. The results of the screening are shown in Figure 3 and Table 2.

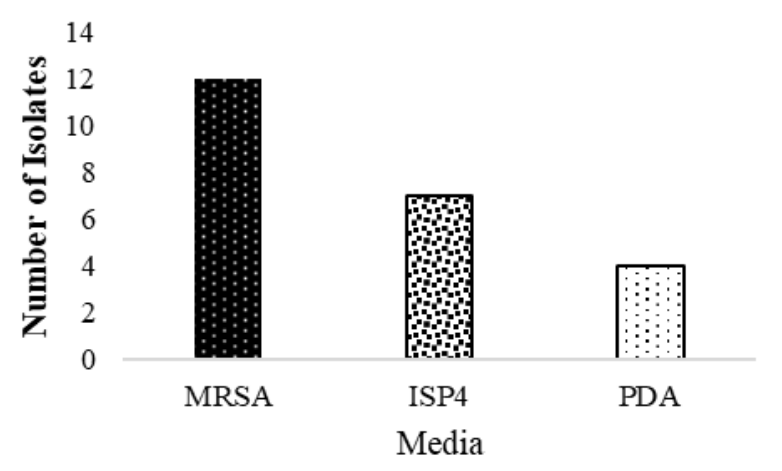

Figure 1. The abundance of cultivable ruminal microorganisms on three different growth media (MRSA and ISP4 for bacteria, PDA medium for fungi) 

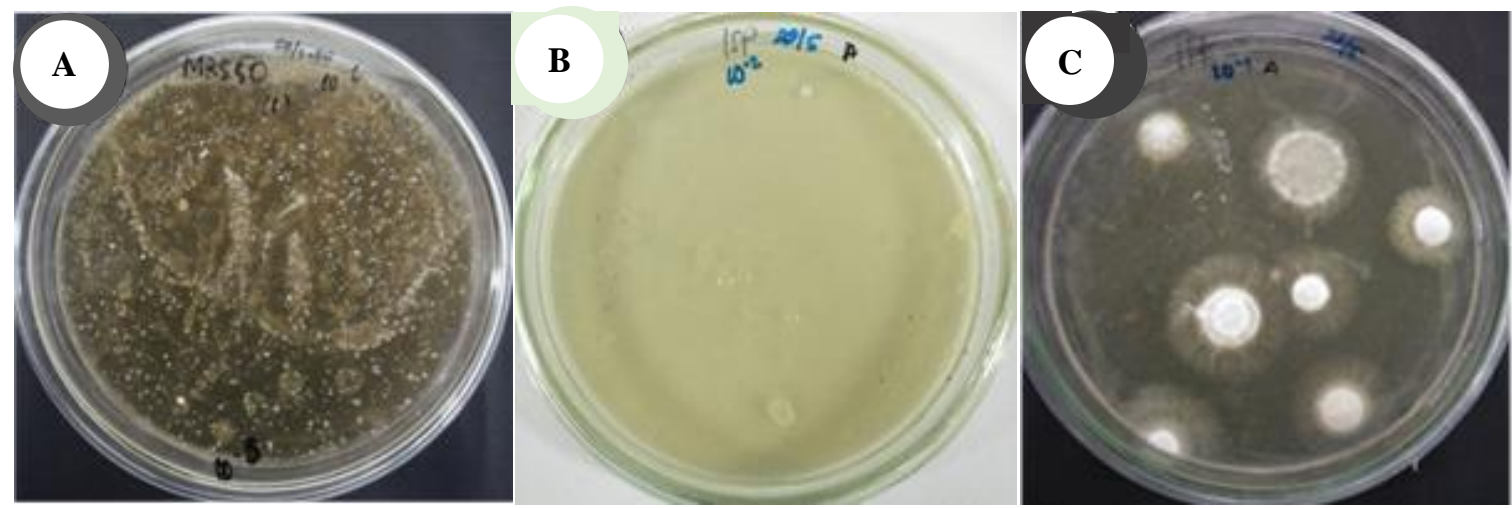

Figure 2. Colonies from ruminal microorganisms on isolation agar media. A. MRS agar, dilution 10-6; B. ISP agar, dilution $10^{-2}$; C. PDA, dilution $10^{-1}$
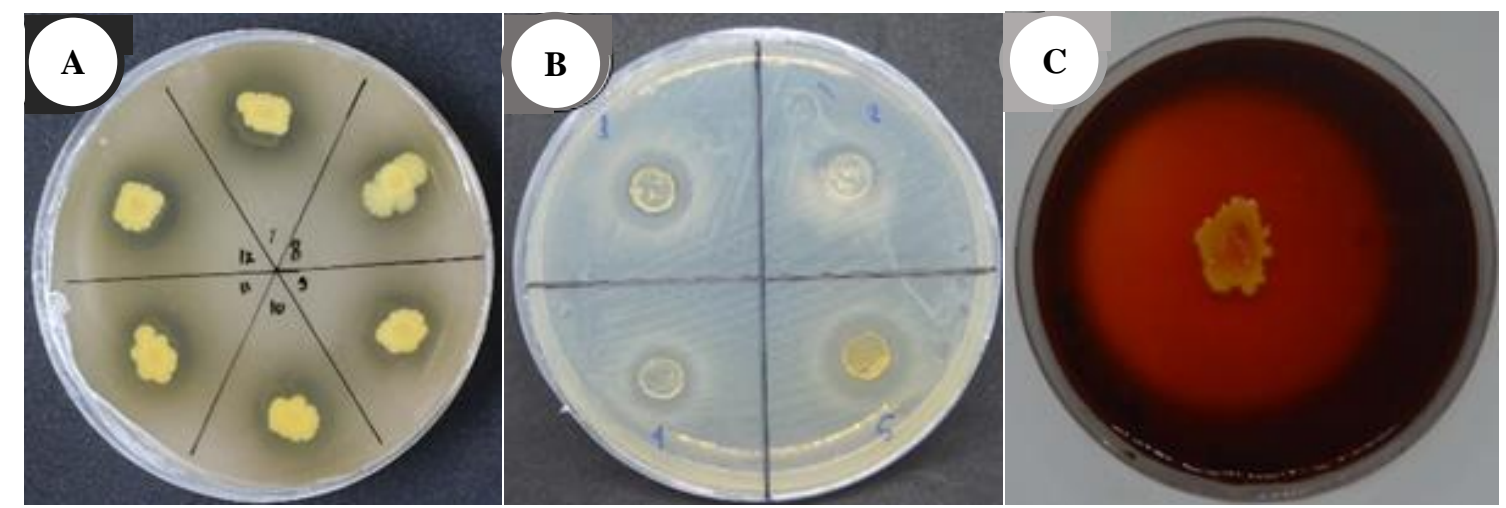

Figure 3. Representative of screening result for (A) lactic acid-producing, (B) antimicrobial activity, and (C) polysaccharide-degrading enzymes

Table 1. Characteristics of ruminal cultivable microorganisms

\begin{tabular}{|c|c|c|c|c|c|c|c|}
\hline \multirow{2}{*}{ Media } & \multirow{2}{*}{ Code } & \multirow{2}{*}{ Colony Form } & \multirow{2}{*}{ Elevation } & \multirow{2}{*}{ Margin } & \multirow{2}{*}{ Colour } & \multicolumn{2}{|c|}{ Respiration } \\
\hline & & & & & & Anaerobic & Aerobic \\
\hline \multirow{12}{*}{$\begin{array}{l}\text { MRSA } \\
\text { agar }\end{array}$} & R.1 & Circular & Convex & Entire & Yellow & + & + \\
\hline & R.2 & Circular & Convex & Entire & Creamy white & + & + \\
\hline & R.3 & Circular & Convex & Entire & Yellow to Brown & + & + \\
\hline & R.4 & Circular & Convex & Entire & Creamy white & + & + \\
\hline & R.5 & Circular & Convex & Entire & Creamy white & + & + \\
\hline & R.6 & Circular & Convex & Entire & Creamy white & + & + \\
\hline & R.7 & Circular & Convex & Entire & Creamy white & + & + \\
\hline & R. 8 & Circular & Convex & Entire & Creamy white & + & + \\
\hline & R.9 & Circular & Convex & Entire & Creamy white & + & + \\
\hline & R. 10 & Circular & Convex & Entire & Creamy white & + & + \\
\hline & R.11 & Circular & Convex & Entire & Brown & + & + \\
\hline & R. 12 & Circular & Convex & Entire & Creamy white & + & + \\
\hline \multirow{6}{*}{$\begin{array}{l}\text { ISP4 } \\
\text { agar }\end{array}$} & Rum 3 & Filamentous & Umbonate & Filiform & White & - & + \\
\hline & Rum 5 & Circular & Raised & Entire & Black & + & + \\
\hline & Rum 6 & Circular & Raised & Entire & Yellowish & + & + \\
\hline & Rum 7 & Filamentous & Umbonate & Filiform & White & - & + \\
\hline & Rum 8 & Filamentous & Umbonate & Filiform & White & - & + \\
\hline & Rum 11 & Circular & Raised & Entire & Orange & + & + \\
\hline \multirow[t]{4}{*}{ PDA } & FR 1 & Cotton & Circular & Crateriform & White & + & + \\
\hline & FR 2 & Filamentous & Circular & Flat & White & + & + \\
\hline & FR 3 & Filamentous & Irregular & Flat & White & + & + \\
\hline & FR 4 & Powdery & Irregular & Raised & White & + & + \\
\hline
\end{tabular}

Note: "+": means the microorganisms grew in the particular respiration 
Table 2. Antimicrobial activity and production of polysaccharidedegrading enzymes

\begin{tabular}{|c|c|c|c|c|c|c|}
\hline \multirow[b]{2}{*}{ Isolate } & \multirow{2}{*}{ 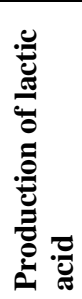 } & \multicolumn{2}{|c|}{$\begin{array}{c}\text { Antimicrobial } \\
\text { activity }\end{array}$} & \multicolumn{3}{|c|}{$\begin{array}{c}\text { Polysaccharide- } \\
\text { degrading enzymes }\end{array}$} \\
\hline & & $\begin{array}{l}-1 \\
8 \\
0\end{array}$ & 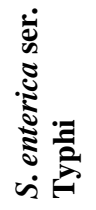 & 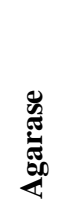 & 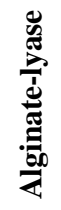 & שֶ. \\
\hline R.1 & + & + & + & - & - & - \\
\hline R. 2 & + & + & + & - & - & - \\
\hline R.3 & + & + & + & - & - & - \\
\hline R.4 & + & + & + & - & - & - \\
\hline R.5 & + & + & + & - & - & - \\
\hline R. 6 & + & + & + & - & - & - \\
\hline R.7 & + & + & + & - & - & - \\
\hline R. 8 & + & + & + & - & - & - \\
\hline R.9 & + & + & + & - & - & - \\
\hline R.10 & + & + & + & - & - & - \\
\hline R.11 & + & + & + & - & - & - \\
\hline R. 12 & + & + & + & - & - & - \\
\hline Rum 3 & NT & - & - & - & - & - \\
\hline Rum 5 & NT & - & - & + & - & - \\
\hline Rum 6 & NT & - & - & - & - & - \\
\hline Rum 7 & NT & - & - & - & - & - \\
\hline Rum 8 & NT & - & - & - & - & - \\
\hline Rum 11 & NT & - & - & - & - & - \\
\hline FR 1 & NT & - & - & + & + & + \\
\hline FR 2 & NT & - & - & + & - & + \\
\hline FR 3 & NT & - & - & + & + & + \\
\hline FR 4 & NT & - & - & - & + & + \\
\hline
\end{tabular}

Note: "+": means the presence of degradation zone, "-": means the absence of degradation zone, NT: means not tested

Table 3. The result of BLAST homology analysis

\begin{tabular}{llll}
\hline Media & Isolate & \multicolumn{1}{c}{ Reference strain } & $\begin{array}{l}\text { Sim. } \\
(\%)\end{array}$ \\
\hline MRSA & R.1 & Lactobacillus plantarum NR 115605.1 & 100 \\
agar & R.2 & Pediococcus acidilactici GL397069 & 99.76 \\
& R.3 & Lactobacillus plantarum NR 115605.1 & 100 \\
& R.4 & Pediococcus acidilactici GL397069 & 99.88 \\
& R.5 & Pediococcus acidilactici GL397069 & 99.71 \\
& R.6 & Pediococcus acidilactici GL397069 & 99.46 \\
& R.7 & Pediococcus acidilactici GL397069 & 99.19 \\
R.8 & Pediococcus acidilactici GL397069 & 99.46 \\
& R.9 & Pediococcus acidilactici GL397069 & 98.98 \\
& R.10 & Pediococcus acidilactici GL397069 & 99.05 \\
& R.11 & Alcaligenes faecalis MW133775.1 & 98.78 \\
& R.12 & Pediococcus acidilactici GL397069 & 99.78
\end{tabular}

ISP4 Rum 3 Streptomyces radiopugnans NR 044013.199.87 agar $\quad$ Rum 5 Massilia suwonensis NR 116872.1 99.26 Rum 6 Achromobacter ruhlandii NR 027197.1 97.86 Rum 7 Streptomyces koyangensis NR 025662.1 100 Rum 8 Streptomyces albus NR 118467.1 99.87 Rum 11 Pseudomonas poae NR 028986.1 99.81

PDA FR 1 Syncephalastrum monosporum var. monosporum MH862279.1

FR 2 Geotrichum candidum KC111882.1

FR 3 Geotrichum candidum KC111882.1

FR $4 \quad$ Aspergillus sydowii KJ413376.1
The screening result showed that all isolates from MRS agar produced lactic acid and antimicrobial agents to inhibit MDR E. coli and S. enterica ser. Typhi. However, these isolates did not produce any polysaccharide-degrading enzyme. Among all isolates from ISP4, Rum 5 showed antibacterial potency against $E$. coli and possessed an agarase activity, while, Rum 6 only exhibited antibacterial potency against $E$. coli. Further, ruminal fungi did not show any antimicrobial potency. Nevertheless, isolate FR1 and FR3 gave positive results for agarase, alginate-lyase, and carrageenase. Isolate FR2 exhibited agarase and carrageenase activities, whereas FR4 exhibited positive results for alginate-lyase and carrageenase activities. The data highlighted that ruminal bacteria were more potent as the source of antimicrobial compounds while ruminal fungi were more potent for enzyme production. These results are supported by the previous study of Oyama et al. (2017) which stated ruminal bacteria produced some prospective antimicrobial peptides (AMPs), namely Lynronne-1, Lynronne-2, and Lynronne-3. These AMPs demonstrated potential antibacterial activity against several MDR pathogens such as Acinetobacter baumannii, Klebsiella pneumoniae, Pseudomonas aeruginosa and , S. aureus. Moreover, a recent study by Sabino et al. (2020) unveiled another AMPs from lasso peptides group. The ruminal bacteria and fungi have been noted to have a vital role in degrading polysaccharides in the rumen. In addition, Dai et al. (2015) reported that bacteria played the dominant key role in polysaccharides degradation. Bacteroides, Butyrivibrio, Clostridium, Fibrobacter, Prevotella, and Ruminococcus are several ruminal bacterial genera that produce polysaccharidedegrading enzymes (Dai et al. 2015; Palevich et al. 2020). However, this study only found one bacterium that degraded the polysaccharides. It was suggested that the media and condition in this study could not support the isolation of polysaccharide-degrading bacteria. All ruminal microorganisms are identified using DNA barcoding approach. The result of BLAST and phylogenetic tree reconstruction are shown in Table 3, Figures 4 and 5.

The result of BLAST homology analysis in Table 3 showed the species of all isolated ruminal microorganisms. Among twelve bacteria from MRS agar, eleven isolates were identified as Pediococcus acidilactici (R.2; R.4-R.10; R.12) and Lactobacillus plantarum (R.1; R.3), while, R.11 was suggested as Alcaligenes faecalis. Furthermore, $P$. acidilactici and L. plantarum are well known as lactic acid bacteria widely isolated from various sources (Nuraida 2015; Alhaag et al. 2019). Moreover, previous studies successfully reported $L$. plantarum and $P$. acidilactici from rumen greens and liquor of cow, sheep, avian, etc (Cobos et al. 2011; Han et al. 2014; Herdian et al. 2018). LAB is defined as a group of gram-positive bacteria, non-sporeforming, has cocci or rods shape, and produces lactic acid as the major product of carbohydrate fermentation (Górska et al. 2019; Setyawardani and Sumarmono 2019). The LAB is a flora normal in the rumen of young ruminant animals, and the composition will decrease in line with maturity. In addition, the presence of L. plantarum and P. acidilactici in a rumen is suspected transient due to the feed variation (Doyle et al. 2019; Stewart 1992). 


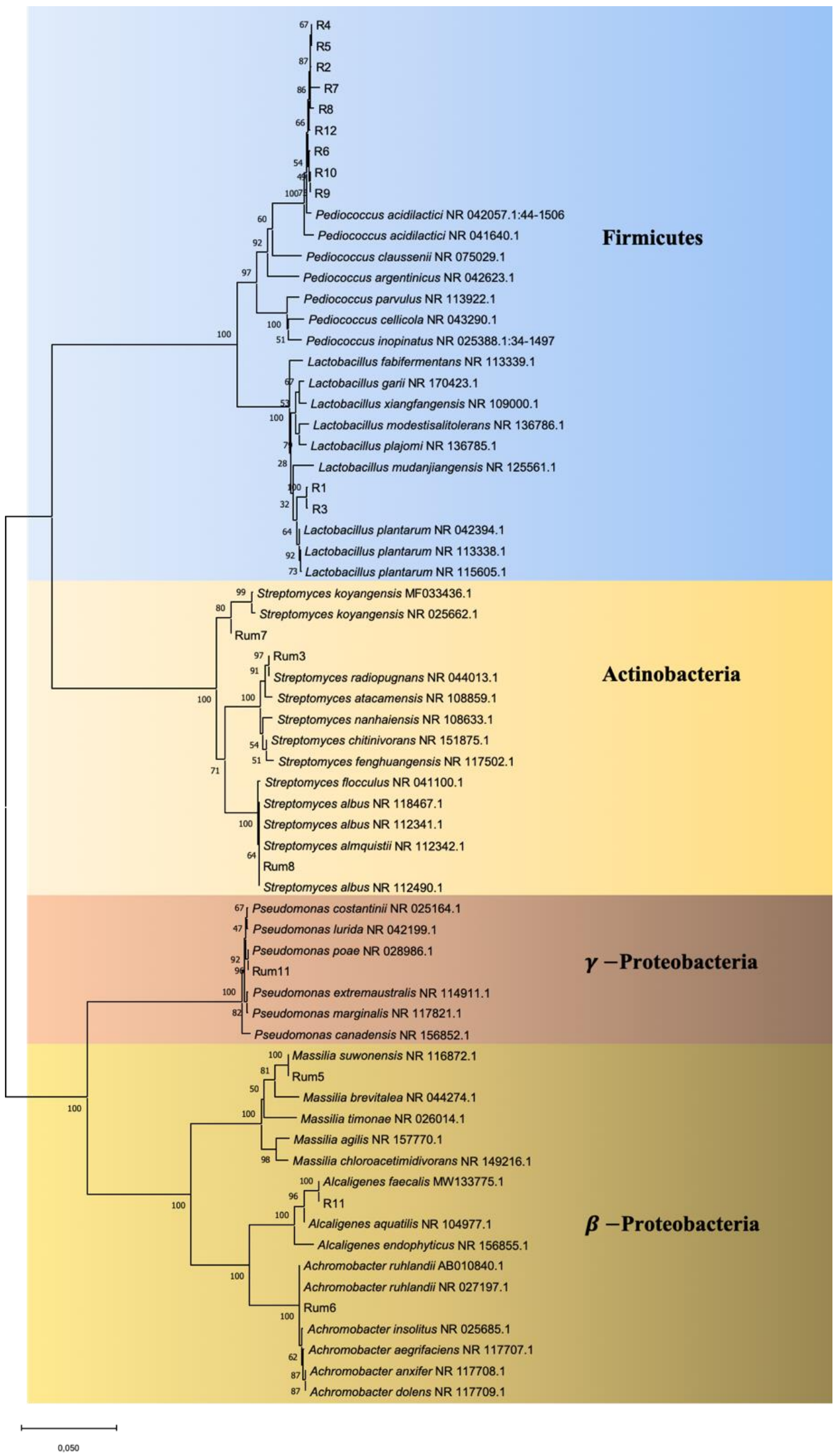

Figure 4. Phylogenetic tree of ruminal bacteria according to $16 \mathrm{~S}$ rDNA analysis 


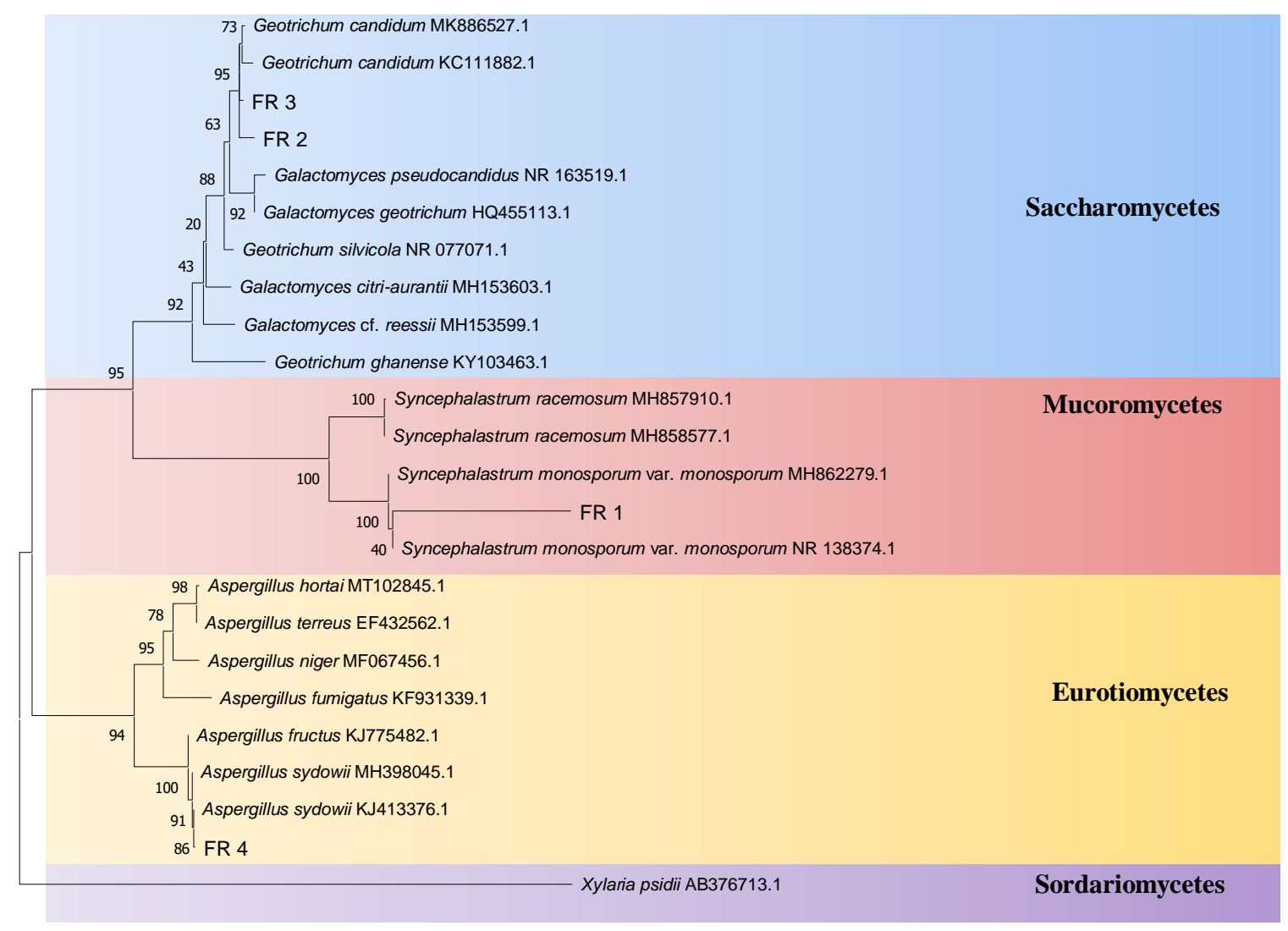

Figure 5. Phylogenetic tree of ruminal fungi according to ITS region analysis

The LAB has essential roles in controlling the composition of ruminal microbiota, reducing methane production, promoting ruminant's health, and increasing milk and meat quality (Stewart 1992; Doyle et al. 2019; O'Hara et al. 2020). Due to the characteristic of LAB, A. faecalis R11 is not suggested as a lactic acid bacteria since this bacterium is gram-negative. This bacteria lives in water, soil, and inhabit vertebrate intestinal tracts (Batt 2014). In this study, the L. plantarum and P. acidilactici exhibited antimicrobial activity but no polysaccharidedegrading enzyme production. As mentioned before, most LAB produce bioactive peptides with prospective activity as antimicrobial agents. Furthermore, Doyle et al. (2019) stated that LAB is not responsible for the degradation of the polysaccharides in the rumen since it can not initiate the metabolism of plant cell walls. Molecular identification of non-LAB bacteria from ISP4 agar in Table 3 shows Rum 3 as Streptomyces radiopugnans, Rum 5 as Massilia suwonensis, Rum 6 as Achromobacter ruhlandii, Rum 7 as S. koyangensis, Rum 8 as S. albus, and Rum 11 as Pseudomonas poae. It was noted that Rum 3, Rum 7, and Rum 8 are the member of Actinobacteria class; while Rum 5, Rum 6 and Rum 11 are Proteobacteria class. These two bacterial classes have been reported to inhabit the rumen (Jami et al. 2013; Dai et al. 2015; Li and Guan 2017). The existence of Streptomycess spp., M. suwonensis, P. poae, and $A$. ruhlandii in the rumen are suspected to be related to the microbiota harboring the feed and water. The role of these specific bacteria in the rumen is barely reported; however, some other members of Proteobacteria are expected to have metabolic roles to degrade cellulose, hemicellulose, and oligosaccharides (Dai et al. 2015). In addition, this study also provides a first report of the agardegrading ability of $M$. suwonensis.

To summary in the present study, eleven LAB isolates, seven non-LAB, and four fungi were successfully isolated from a cow's rumen. All LAB isolates were suggested as a prospective source of antimicrobial compounds, while, the ruminal fungi as source of polysaccharide-degrading enzymes. Furthermore, several bacterial and fungal classes were isolated in this study namely, actinobacteria, bacilli, $\gamma$-proteobacteria, $\beta$-proteobacteria, Saccharomycetes, Eurotiomycetes, and Mucoromycetes. A further analysis is proposed as future study to understand the potential of isolated LAB as future probiotics. In addition, the ruminal fungi with polysaccharide-degrading enzyme potential should be investigated to degrade the complex carbohydrate and enzyme productions.

\section{ACKNOWLEDGEMENTS}

We thank to Universitas Diponegoro, Semarang, Indonesia for funding this research through Riset Publikasi Internasional (RPI) scheme with contract number 23321/UN7.6.1/PP/2020. 


\section{REFERENCES}

Alhaag H, Yuan X, Mala A, Bai J, Shao T. 2019. Fermentation characteristics of Lactobacillus plantarum and Pediococcus species isolated from sweet sorghum silage and their application as silage inoculants. Appl Sci 9 (6). DOI: 10.3390/app9061247.

Ayuningrum D, Sibero MT, Kristiana R, Asagabaldan MA, Wuisan ZG, Trianto A, Radjasa OK, Sabdono A, Schaberle TF. 2019. Tunicateassociated bacteria show a great potential for the discovery of antimicrobial compounds. PLOS One 14 (3): e0213797. DOI: 10.1371/journal.pone.0213797.

Ayuningtyas EP, Sibero MT, Hutapea NEB, Frederick EH, Murwani R, Zilda DS, Wijayanti DP, Sabdono A, Pringgenies D, Radjasa OK 2021. Screening of extracellular enzyme from Phaeophyceaeassociated fungi. IOP Conf Ser: EES 750 (1): 012005. DOI: 10.1088/1755-1315/750/1/012005.

Balch DA, Rwoland SJ. 1957. Volatile fatty acids and lactic acid in the rumen of dairy cows receiving a variety of diets. Br J Nutr 11 (3) 288-298. DOI: 10.1079/BJN19570046.

Batt CA. 2014. Encyclopedia of food microbiology. Academic press. DOI: 10.1016/B978-0-12-384730-0.00006-9.

Castillo-González AR, Burrola-Barraza ME, Domínguez-Viveros J, Chávez-Martínez A. 2014. Rumen microorganisms and fermentation. Arch Med Vet 46: 349-361. DOI: 10.4067/S0301 732 X2014000300003.

Cobos MA, de Coss AL, Ramirez ND, Gonzalez SS, Cerrato FR. 2011 Pediococcus acidilactici isolated from the rumen of lambs with rumen acidosis, $16 \mathrm{~S}$ rRNA identification and sensibility to monensin and lasalocid. Res Vet Sci 90 (1): 26-30. DOI: 10.1016/j.rvsc.2010.05.006.

Comlekcioglu U, Ozkose E, Yazdic FC, Akyol I, Ekinci MS. 2010. Polysaccharidase and glycosidase production of avicel grown rumen fungus Orpinomyces sp. GMLF5. Act Biol Hungarica 61 (3): 333 343. DOI: 10.1556/ABiol.61.2010.3.9.

Dai X, Tian Y, Li J, Su X, Wang X, Zhao S, Liu L, Luo Y, Liu D, Zheng H, Wang J, Dong Z, Hu S, Huang L. 2015. Metatranscriptomic analyses of plant cell wall polysaccharide degradation by microorganisms in the cow rumen. Appl Environ Microbiol 81 (4) 1375-1386. DOI: 10.1128/AEM.03682-14.

Doyle N, Mbandlwa P, Kelly WJ, Attwood G, Li Y, Ross RP, Stanton C, Leahy S. 2019. Use of lactic acid bacteria to reduce methane production in ruminants, a critical review. Front Microbiol 10: 2207. DOI: $10.3389 /$ fmicb.2019.02207.

Ejtahed HS, Angoorani P, Soroush AR, Atlasi R, Hasani-Ranjbar S, Mortazavian AM, Larijani B. 2019. Probiotics supplementation for the obesity management: a systematic review of animal studies and clinical trials. J Funct Foods 52: 228-242. DOI: 10.1016/j.jff.2018.10.039.

Górska A, Przystupski D, Niemczura MJ, Kulbacka J. 2019. Probiotic bacteria: a promising tool in cancer prevention and therapy. Curr Microbiol 76 (8): 939-949. DOI: 10.1007/s00284-019-01679-8.

Guo L, Yao D, Li D, Lin Y, Bureenok S, Ni K, Yang F. 2020. Effects of lactic acid bacteria isolated from rumen fluid and feces of dairy cows on fermentation quality, microbial community, and in vitro digestibility of alfalfa silage. Front Microbiol 10: 1-11. DOI: 10.3389/fmicb.2019.02998

Gurpilhares DB, Cinelli LP, Simas NK, Pessoa A, Sette LD. 2019. Marine prebiotics: polysaccharides and oligosaccharides obtained by using microbial enzymes. Food Chem 280: 175-186. DOI: 10.1016/j.foodchem.2018.12.023

Han H, Ogata Y, Yamamoto Y, Nagao S, Nishino N. 2014. Identification of lactic acid bacteria in the rumen and feces of dairy cows fed total mixed ration silage to assess the survival of silage bacteria in the gut. J Dairy Sci 97 (9): 5754-5762. DOI: 10.3168/jds.2014-7968.

Herdian H, Istiqomah L, Damayanti E, Suryani AE, Anggraeni AS, Rosyada N, Susilowati A. 2018. Isolation of cellulolytic lactic-acid bacteria from Mentok (Anas moschata) gastro-intestinal tract. Trop Anim Sci J 41 (3): 200-206. DOI: 10.5398/tasj.2018.41.3.200

Hu B, Gong Q, Wang Y, Ma Y, Li J, Yu W. 2006. Prebiotic effect of neoagaro-oligosaccharides prepared by enzymatic hydrolysis of agarose. Anaerobe 12: 260-266. DOI 10.1016/j.anaerobe.2006.07.005

Hutapea NEB, Sibero MT, Ayuningtyas EP, Frederick EH, Wijayanti DP Sabdono A, Pringgenies D, Radjasa OK, Zilda, DS, Murwani, R. 2021. Seaweed-associated fungi from Sepanjang Beach,
GunungKidul, Yogyakarta as potential source of marine polysaccharides-degrading enzymes. IOP Conf Ser: EES 750 (1): 012007. DOI: $10.1088 / 1755-1315 / 750 / 1 / 012007$

Jami E, Israel A, Kotser A, Mizrahi I. 2013. Exploring the bovine rumen bacterial community from birth to adulthood. ISME J 7 (6): 10691079. DOI: $10.1038 /$ ismej.2013.2

Jannah SN, Saraswati TR, Handayani D, Pujiyanto S. 2018. Antibacterial activity of lactic acid bacteria isolated from gastrointestinal tract of "ayam kampung" chicken against food pathogens. J Phys: Conf Ser 1025 (1): 012082. DOI: 10.1088/1742-6596/1025/1/012082.

Jose VL, More RP, Appoothy T, Arun AS. 2017. In depth analysis of rumen microbial and carbohydrate-active enzymes profile in Indian crossbred cattle. Syst Appl Microbiol 40 (3): 160-170. DOI: 10.1016/j.syapm.2017.02.003

Jutur PP, Nesamma AA, Shaikh KM. 2016. Algae-derived marine oligosaccharides and their biological applications. Front Mar Sci 3: 15. DOI: $10.3389 /$ fmars.2016.00083.

Kharel MK, Shepherd MD, Nybo SE, Smith ML, Bosserman MA, Rohr J. 2010. Isolation of Streptomyces species from soil. Curr Protoc Microbiol 19: 1-5. DOI: 10.1002/9780471729259.mc10e04s19.

Kocsis T, Molnár B, Németh D, Hegyi P, Szakács Z, Bálint A, Garami A, Soós A, Márta K, Solymár M. 2020. Probiotics have beneficial metabolic effects in patients with type 2 diabetes mellitus: a metaanalysis of randomized clinical trials. Sci Rep 10 (1): 1-14. DOI: 10.1038/s41598-020-68440-1.

Li F, Guan LL. 2017. Metatranscriptomic profiling reveals linkages between the active rumen microbiome and feed efficiency in beef cattle. Appl Environ Microbiol 83 (9): 1-16. DOI: 10.1128/AEM.00061-17.

Liu J, Yang S, Li X, Yan Q, Reaney MJT, Jiang Z. 2019. ALginate oligosaccharides: production, biological activities, and potential applications. Compr Rev Food Sci Food Saf 18: 1859-1881. DOI: $10.1111 / 1541-4337.12494$

Mano MCR, Numa IAN, da Silva JB, Paulino BN, Pessoa MG, Pastore GM. 2017. Oligosaccharide biotechnology : an approach of prebiotic revolution on the industry. Appl Microbiol Biotech 102 (1): 17-37. DOI: $10.1007 / \mathrm{s} 00253-017-8564-2$

Matthews C, Crispie F, Lewis E, Reid M, O'Toole PW, Cotter PD. 2019. The rumen microbiome: a crucial consideration when optimising milk and meat production and nitrogen utilisation efficiency. Gut Microbes 10 (2): 115-132. DOI: 10.1080/19490976.2018.1505176.

Mezaini A, Chihib NE, Bouras DA, Nedjar-Arroume N, Hornez JP. 2009. Antibacterial activity of some lactic acid bacteria isolated from an algerian dairy product. J Environ Pub Health. DOI: $10.1155 / 2009 / 678495$.

Monika, Savitri, Kumar V, Kumari A, Angmo K, Bhalla TC. 2017. Isolation and characterization of lactic acid bacteria from traditional pickles of Himachal Pradesh, India. J Food Sci Technol 54 (7): 19451952. DOI: 10.1007/s13197-017-2629-1.

Nagpal R, Kumar A, Kumar M, Behare PV, Jain S, Yadav H. 2012. Probiotics, their health benefits and applications for developing healthier foods: a review. FEMS Microbiol Lett 334 (1): 1-15. DOI: 10.1111/j.1574-6968.2012.02593.x

Noel SJ, Olijhoek DW, Mclean F, Lovendahl P, Lund P, Hojberg O. 2019. Rumen and fecal microbial community structure of Holstein and Jersey dairy cows as affected by breed, diet, and residual feed intake. Animals 9 (498). DOI: 10.3390/ani9080498.

Nordgård CT, Rao SV, Draget KI. 2019. The potential of marine oligosaccharides in pharmacy. Bioact Carbohydr Diet Fibre 18: 1-4. DOI: $10.1016 /$ j.bcdf.2019.100178

Nuraida L. 2015. A review: health promoting lactic acid bacteria in traditional Indonesian fermented foods. Food Sci Human Wellness 4 (2): 47-55. DOI: 10.1016/j.fshw.2015.06.001.

O'Hara E, Neves ALA, Song Y, Guan LL. 2020. The role of the gut microbiome in cattle production and health: driver or passenger? Ann Rev Anim Biosci 8: 199-220. DOI: 10.1146/annurev-animal-021419083952 .

Oyama LB, Girdwood SE, Cookson AR, Fernandez-Fuentes N, Privé F, Vallin HE, Wilkinson TJ, Golyshin PN, Golyshina OV, Mikut R, Hilpert K, Richards J, Wootton M, Edwards JE, Maresca M, Perrier J, Lundy FT, Luo Y, Zhou M, Hess M, Mantovani HC, Creevey CJ, Huws SA. 2017. The rumen microbiome: an underexplored resource for novel antimicrobial discovery. Npj Biofilms Microbiomes 3 (1): 1-9. DOI: 10.1038/s41522-017-0042-1.

Palevich N, Kelly WJ, Leahy SC, Denman S, Altermann E, Rakonjac J, Attwood GT. 2020. Comparative genomics of rumen Butyrivibrio 
spp. uncovers a continuum of polysaccharide-degrading capabilities. Appl Environ Microbiol 86 (1): 1-19. DOI: 10.1128/AEM.01993-19.

Paz HA, Hales KE, Wells JE, Kuehn LA, Freetly HC, Berry ED, Flythe MD, Spangler ML, Fernando SC. 2018. Rumen bacterial community structure impacts feed efficiency in beef cattle. J Anim Sci 96 (3): 1045-1058. DOI: $10.1093 / \mathrm{jas} / \mathrm{skx} 081$.

Pushpangadan P, George V, Ijinu TP, Chithra MA. 2018. Biodiversity, bioprospecting, traditional knowledge. sustainable development and value added products: A review. J Tradit Med Clin Naturopathy 7 (1): $1-7$.

Sabino YNV, de Araujo KC, de Assis FGDV, Moreira SM, Lopes TDS, Mendes TADO, Huws SA, Mantovani HC. 2020. In silico screening unveil the great potential of ruminal bacteria synthesizing lasso peptides. Front Microbiol 11: 1-17. DOI: $10.3389 /$ fmicb. 2020.576738 .

Setyawardani T, Sumarmono J. 2019. Isolation and antimicrobial activities of lactic acid bacteria originated from Indonesian local goat's colostrum. Anim Prod 20 (3). DOI: 10.20884/1.jap.2018.20.3.731.

Sibero MT, Bachtiarini TU, Trianto A, Lupita AH, Sari DP, Igarashi Y, Harunari E, Sharma AR, Radjasa OK, Sabdono A. 2019. Characterization of a yellow pigmented coral-associated bacterium exhibiting antibacterial activity against multidrug resistant (MDR) organism. Egypt $\mathrm{J}$ Aquat Res 45 (1): 81-87. DOI: 10.1016/j.ejar.2018.11.007

Sibero MT, Sahara R, Syafiqoh N, Tarman K. 2017. Antibacterial activity of red pigment isolated from coastal endophytic fungi against multidrug resistant bacteria. Biotropia 24 (2): 161-172. DOI: 10.11598/btb.2017.24.2.725.

Sibero MT, Triningsih D, Radjasa OK, Sabdono A, Trianto A, Priyani N, Prastyo A. 2018. Antimicrobial activity of sponge-associated fungi from Pandang Island, North Sumatera against clinical pathogenic microorganisms. Asian J Microbiol Biotechnol Environ Sci 20 (1): 142-149.

Stewart CS. 1992. Lactic Acid Bacteria in the Rumen. In The Lactic Acid Bacteria. DOI: 10.1007/978-1-4615-3522-5_3.

Stieglmeier M, Wirth R, Kminek G, Moissl-Eichinger C. 2009 Cultivation of anaerobic and facultatively anaerobic bacteria from spacecraft-associated clean rooms. Appl Environ Microbiol 75 (11): 3484-3491. DOI: 10.1128/AEM.02565-08.

Swift CL, Brown JL, Seppälä S, O’Malley MA. 2019. Co-cultivation of the anaerobic fungus Anaeromyces robustus with Methanobacterium bryantii enhances transcription of carbohydrate active enzymes. J Indus Microbiol Biotechnol 46: 1427-1433. DOI: 10.1007/s10295019-02188-0.

Tapio I, Fischer D, Blasco L, Tapio M, Wallace RJ, Bayat AR, Ventto L, Kahala M, Negussie E, Shingfield KJ, Vilkki J. 2017. Taxon abundance, diversity, co-occurrence and network analysis of the ruminal microbiota in response to dietary changes in dairy cows. PLoS ONE 12 (7): e0180260. DOI: 10.1371/journal.pone.0180260.

Tapio I, Snelling TJ, Strozzi F, Wallace RJ. 2017. The ruminal microbiome associated with methane emissions from ruminant livestock. J Anim Sci Biotechnol 8 (1): 1-11. DOI: 10.1186/s40104017-0141-0.

Techo S, Visessanguan W, Vilaichone RK, Tanasupawat S. 2019. Characterization and antibacterial activity against Helicobacter pylori of lactic acid bacteria isolated from Thai fermented rice noodle. Probiotics Antimicrob Proteins 11 (1): 92-102. DOI: 10.1007/s12602018-9385-z.

Trianto A, Radjasa OK, Sibero MT, Sabdono A, Armono HD, Igarashi Y. 2020. The effect of culture media on the number and bioactivity of marine invertebrates associated fungi. Biodiversitas 21 (1): 407-412. DOI: 10.13057/biodiv/d210147.

Wang B, Ma MP, Diao QY, Tu Y. 2019. Saponin-induced shifts in the rumen microbiome and metabolome of young cattle. Front Microbiol 10: 1-14. DOI: 10.3389/fmicb.2019.00356.

Wang X, Li X, Zhao C, Hu P, Chen H, Liu Z, Liu G, Wang Z. 2012. Correlation between composition of the bacterial community and concentration of volatile fatty acids in the rumen during the transition period and ketosis in dairy cows. Appl Environ Microbiol 78 (7): 2386-2392. DOI: 10.1128/AEM.07545-11.

Wang Y, McAllister TA. 2002. Rumen microbes, enzymes and feed digestion-A review. Asian-Australasian J Anim Sci 15 (11): 16591676. DOI: 10.5713 /ajas.2002.1659.

Wijaya AP, Bondar KG, Frederick EH, Igarashi Y, Sibero MT. 2020. Identification of marine bacteria HPP.4A and HPP.T13 and its anticancer activity against P388 murine leukaemia cell. IOP Conf Ser: EES 584 (1): 012005. DOI: 10.1088/1755-1315/584/1/012005.

Wijaya AP, Sibero MT, Zilda DS, Windiyana AN, Wijayanto A, Frederick EH, Murwani R, Wijayanti DP, Sabdono A, Pringgenies D, Radjasa OK. 2021. Preliminary screening of carbohydrase-producing bacteria from Chaetomorpha sp. in Sepanjang Beach, Yogyakarta, Indonesia. IOP Conf Ser: EES 750 (1): 012027. DOI: 10.1088/1755$1315 / 750 / 1 / 012027$

Yu Y, Shen M, Song Q, Xie J. 2018. Biological activities and pharmaceutical applications of polysaccharide from natural resources: A review. Carbohydr Polym 183 (235): 91-101. DOI: 10.1016/j.carbpol.2017.12.009.

Zhu B, Ni F, Xiong Q, Yao Z. 2020. Marine oligosaccharides originated from seaweeds: source, preparation, structure, physiological activity and applications. Crit Rev Food Sci Nutr 61 (1): 60-74. DOI: $10.1080 / 10408398.2020 .1716207$ 